\title{
Stable isotopes from multiple tissues reveal diet switching in sharks
}

\author{
M. Aaron MacNeil ${ }^{1,3}$, Gregory B. Skomal ${ }^{2}$, Aaron T. Fisk ${ }^{1, *}$ \\ ${ }^{1}$ Warnell School of Forest Resources, University of Georgia, Athens, Georgia 30606, USA \\ ${ }^{2}$ Martha's Vineyard Marine Fisheries Field Station, Massachusetts Division of Marine Fisheries, PO Box 68, \\ Vineyard Haven, Massachusetts 02568, USA \\ ${ }^{3}$ Present address: Department of Marine Science and Technology, University of Newcastle, Newcastle upon Tyne NE1 7RU, UK
}

\begin{abstract}
Food web relationships in marine systems have traditionally been defined through stomach content analysis, but biochemical techniques have recently emerged to validate and broaden temporal diet patterns. Stable isotope analysis has become a practical tool for evaluating these relationships in aquatic systems; however, routine sampling of muscle tissue captures only part of the trophic information available from each animal. We compared $\delta^{15} \mathrm{~N}$ and $\delta^{13} \mathrm{C}$ values among liver, muscle and cartilage in the blue shark Prionace glauca, shortfin mako Isurus oxyrinchus, and common thresher Alopias vulpinus from the northwest Atlantic to show how multiple-tissue sampling captured feeding relationships which would have been invisible to muscle tissue alone. Specifically, we demonstrated evidence of a cephalopod to bluefish Pomatomus saltatrix diet switch in the shortfin mako in spring, and found that the blue shark and common thresher have consistent diets throughout the year. We concluded that consistency observed among stable isotope values in multiple tissues implied that the fish were in steady-state with the isotope ratios of their diet and that multiple tissues should be used in trophic assessments of large pelagic fishes. Further experiments to quantify the turnover of stable isotopes in different tissues and species are needed to improve the accuracy of stable-isotope analyses .
\end{abstract}

KEY WORDS: $\delta^{15} \mathrm{~N} \cdot \delta^{13} \mathrm{C} \cdot$ Diet $\cdot$ Trophic ecology $\cdot$ Metabolism $\cdot$ Elasmobranch

- Resale or republication not permitted without written consent of the publisher

\section{INTRODUCTION}

Profound declines in large pelagic fish populations (sharks, tunas, and billfishes) have recently become apparent (Jackson et al. 2001, Baum et al. 2003, Myers \& Worm 2003, Baum \& Myers 2004) and ecosystem studies have demonstrated generally that the removal of these fishes from tropical and temperate communities affects the abundance of other fishes, both negatively and positively, across many trophic levels (Stevens et al. 2000, Cox et al. 2002, Essington et al. 2002, Kitchell et al. 2002). These analyses have however, been susceptible to a lack of diet composition data (Cox et al. 2002), and surprisingly little dietary data are available for sharks (Cortés 1999). Two sampling methods, stomach content analysis and stable isotope analysis, can estimate trophic position in marine ecosystems. Although it has provided consider- able information about the trophic ecology of many animals, stomach content analysis has been criticized for the 'snapshot' nature of sampling (Pinnegar \& Polunin 1999, Pinnegar et al. 2001), the prevalence of unrecognized dietary items (Pinnegar et al. 2001), bias from regurgitation during capture (Renones et al. 2002), and the difficulty of obtaining sufficient sampling frequency to draw significant conclusions (Vander Zanden et al. 1997). Biochemical techniques have the potential to complement stomach content analysis and alieviate these biases when present.

Stable nitrogen isotope analysis uses the relative abundances of ${ }^{14} \mathrm{~N}$ and ${ }^{15} \mathrm{~N}$ in animal tissues to estimate trophic position in systems where the concentration of ${ }^{15} \mathrm{~N}$ tends to become enriched in consumers over their diet (Minagawa \& Wada 1984). Nitrogen isotope concentrations are conventionally expressed as $\delta^{15} \mathrm{~N}$, i.e. 10 times the percent ratio of ${ }^{15} \mathrm{~N}$ to ${ }^{14} \mathrm{~N}$, relative to a 
standard (units: \%o; Schoeller 1999). In principle, if there is a consistent degree of enrichment (fractionation) at each trophic step in a community, the $\delta^{15} \mathrm{~N}$ of each animal becomes an index for trophic position relative to the $\delta^{15} \mathrm{~N}$ of the known trophic position of a primary consumer (Minagawa \& Wada 1984, Vander Zanden et al. 1997). Often $\delta^{15} \mathrm{~N}$ values are presented with $\delta^{13} \mathrm{C}$ ratios $\left({ }^{13} \mathrm{C}:{ }^{12} \mathrm{C}\right)$, which, because they are generally conserved at each trophic step in an ecosystem, are useful indicators of dietary carbon source. If 2 or more species have distinct $\delta^{13} \mathrm{C}$ values, this can suggest multiple sources of dietary carbon within an ecosystem.

Cortés (1999) summarized shark stomach content data to estimate the trophic positions of 149 species, concluding that, while stomach content analysis affirmed a generally high trophic position for sharks, stable isotope analysis should be developed to validate dietary results. Fisk et al. (2002) were among the first to estimate a shark's trophic position using stable nitrogen isotopes, finding that $\delta^{15} \mathrm{~N}$ alone was not an appropriate surrogate for trophic position in the Greenland shark Somniosus microcephalus. Most recently, Estrada et al. (2003) concluded that $\delta^{15} \mathrm{~N}$ data agreed with stomach content data from Cortés (1999) and was an appropriate means to estimate the trophic position of the blue shark Prionace glauca, shortfin mako Isurus oxyrinchus, and common thresher Alopias vulpinus sampled from the shelf waters off Martha's Vineyard, MA, USA. However, Fisk et al. (2002) and Estrada et al. (2003) sampled only muscle tissue, and stable isotope analysis of multiple tissue could provide more precise dietary information than muscle sampling alone.

The stable isotope ratios of fish tissues reflect the combined effects of metabolism (the turnover of existing tissue), growth (the addition of new tissue), isotopic routing (incomplete mixing of diet components en route to individual tissues), tissue protein composition (the association of specific stable isotope ratios with specific amino acids), and diet. Tissues with high metabolic rates (e.g. liver) more rapidly reflect changes in dietary $\delta^{15} \mathrm{~N}$ than less metabolically active tissues (e.g. muscle, cartilage) and as a result will reflect a shorter and more recent period of dietary feeding (Tieszen et al. 1983, MacNeil et al. 2005). Diet supplies the majority of isotopes to the body (a small amount of internal recycling may occur) and is, therefore, the primary determinant of $\delta^{15} \mathrm{~N}$ and $\delta^{13} \mathrm{C}$ values. The majority of field studies using stable isotope analysis have been concerned with assessing dietary shifts and assigning trophic position. Studies on fish have primarily sampled isotope ratios in muscle tissue and proceeded under the simple assumption that differences in $\delta^{15} \mathrm{~N}$ values among species solely reflect their individual diets. This model has proved useful in many systems
(Vander Zanden et al. 1997, Hobson et al. 2002) but, as Tieszen et al. (1983) and Hobson \& Clark (1992) have suggested for $\delta^{13} \mathrm{C}$, differences in metabolic turnover rates can also be exploited. If the effects of metabolism can be estimated, $\delta^{15} \mathrm{~N}$ differences among tissues could (1) validate existing estimates of diet, (2) track dietary changes, and (3) reveal additional feeding interactions not observable using previous methods.

Here we related differences in the $\delta^{15} \mathrm{~N}$ signatures among liver, muscle, and cartilage tissues from blue sharks, shortfin makos, and common threshers to known seasonal shifts in diet. Moreover, we show how multiple-tissue sampling for stable isotopes can support stomach content results, as well as help to identify fishes likely to be at steady-state with their diet. We assumed, based on laboratory studies of elasmobranch tissues (MacNeil et al. 2005), that differences in metabolic rates among tissues drive stable isotope ratios in wild sharks, and we hypothesized that multiple-tissue sampling would reveal unique $\delta^{15} \mathrm{~N}$ signatures among tissues that reflect seasonal changes in shark diets. We chose to sample the same system as Estrada et al. (2003) to look for annual variation between muscle $\delta^{15} \mathrm{~N}$ values in the important commercial and recreational fishing area of the George's Bank and Southern New England ecosystems.

\section{MATERIALS AND METHODS}

Site and field sampling. Off the northeast coast of the USA, Martha's Vineyard Island is located $5 \mathrm{~km}$ south of Cape Cod, MA. Continental shelf waters south of Martha's Vineyard support extensive recreational fisheries for sharks, tunas, and billfishes from June to October each year. In July 2002, we collected tissue samples from sharks caught by recreational fishermen on shelf areas approximately 50 to $160 \mathrm{~km}$ south of Martha's Vineyard (Fig. 1) that are known for seasonal aggregations of large pelagic species (Charles 2001). Fish fork length (FL), weight, sex, and maturity were recorded. Fish tissue samples were collected by excising approximately $5 \mathrm{~g}$ of dorsal muscle (along the spine, above the 5th gill slit), liver (anterior portion of either lobe), and cartilage (vertebral sample, directly above the 5th gill slit and subsampled from centrum to vertebral edge). Tissues samples were packed in ice and frozen within $1 \mathrm{~h}$ of sampling. Dietary habits for each species were analyzed from Stillwell \& Kohler (1982), Cortés (1999), Henderson et al. (2001), Preti et al. (2001) and NMFS (2002), and stable isotope estimates of prey were supplied by J. Estrada (unpubl.).

Stable isotope analysis. In the laboratory, liver and muscle tissues were freeze-dried, finely ground with a bench grinder, and lipids were removed by twice agi- 


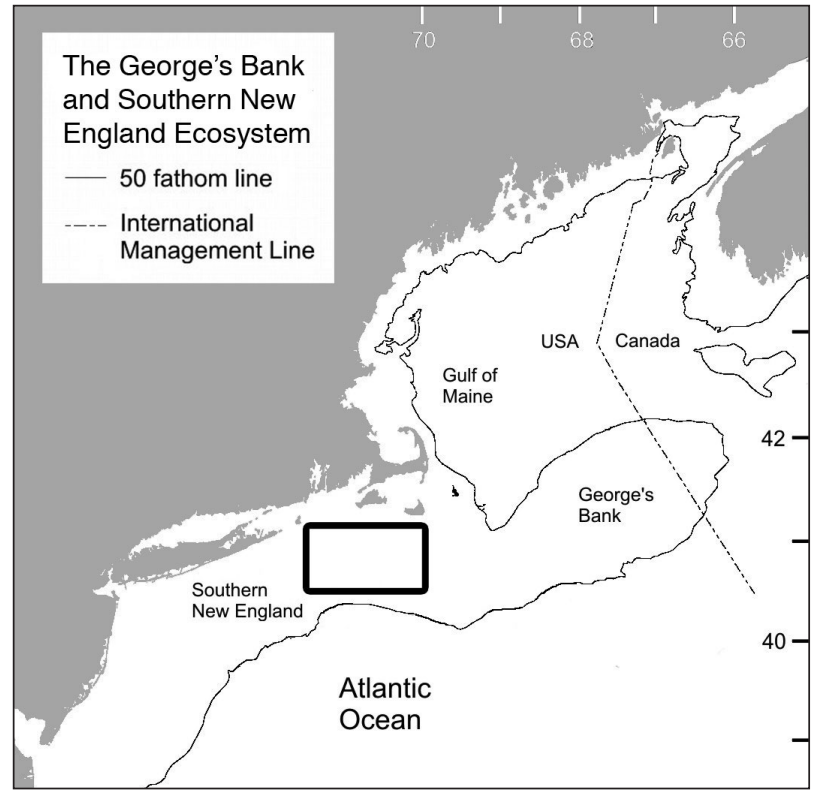

Fig. 1. The George's Bank and Southern New England Ecosystem. Rectangle denotes recreational fishing area where fish used in this study were captured (July 2002)

tating the tissue in a 1:2 chloroform:methanol solution for $24 \mathrm{~h}$ (Hobson \& Welch 1992). Tissue samples were then oven dried at $60^{\circ} \mathrm{C}$ for $48 \mathrm{~h}$ to remove remaining solvent and divided into approximately $1 \mu \mathrm{g}$ subsamples for stable isotope analysis. Sample ${ }^{15} \mathrm{~N} /{ }^{14} \mathrm{~N}$ and ${ }^{13} \mathrm{C} /{ }^{12} \mathrm{C}$ ratios were determined in a Thermo Finnigan DeltaPlus mass-spectrometer (Thermo Finnigan) at the Institute of Ecology, University of Georgia. The precision of the isotopic analyses was 0.15 , based on internal reference samples.

Ratios of heavy to light isotopes were expressed in $\delta$ notation using the equation:

$$
\delta X=\left[\left(\frac{R_{\text {sample }}}{R_{\text {standard }}}\right)-1\right] \times 1000
$$

where $X$ is the heavy isotope, $R_{\text {sample }}$ is the ratio of heavy to light isotope in the sample, and $R_{\text {standard }}$ is the ratio of heavy to light isotope in the reference standard. The standard reference material for carbon was Pee Dee Belemnite and for nitrogen was atmospheric $\mathrm{N}_{2}$.

Statistical analysis. We assessed ${ }^{15} \mathrm{~N}$ and ${ }^{13} \mathrm{C}$ differences among tissues and species by comparing plotted means of $\delta^{15} \mathrm{~N}$ and $\delta^{13} \mathrm{C}$ values and non-parametric bootstrap estimates of dispersion measures using the $\mathrm{R}$ implementation of the $\mathrm{S}$ programming language (Free Software Foundation). Bootstrap distributions $(\hat{F})$ of each tissue-species combination were created by randomly sampling 1000 values, with replacement, from our data; from these distributions, we calculated standard deviations and $95 \%$ confidence intervals.
Assuming normal variances for $\delta^{15} \mathrm{~N}$ and $\delta^{13} \mathrm{~N}$ results, these plots avoided false null hypothesis testing (we assumed a priori that there would be differences among tissues) and are a reasonable basis from which to assess biological differences between isotope ratios, particularly in a sampling study (Johnson 1999). For detailed explanations of the problems associated with using hypothesis testing in uncontrolled sampling studies see Johnson (1999) and Anderson et al. (2000).

\section{RESULTS}

Sampled sharks had a FL of between 178 and $281 \mathrm{~cm}$. We found no size or sex meditated $\delta^{15} \mathrm{~N}$ or $\delta^{13} \mathrm{C}$ differences within species for each tissue type. Intraspecies tissue $\delta^{15} \mathrm{~N}$ differences were present among several tissues - shortfin mako liver was enriched in $\delta^{15} \mathrm{~N}$ over muscle and cartilage; common thresher liver was enriched above cartilage but consistent with muscle-but there were no such differences in $\delta^{15} \mathrm{~N}$ among tissues for blue sharks (Fig. 2). Shortfin mako liver $\delta^{15} \mathrm{~N}$ was, on average, $2.85 \%$ greater than blue shark liver, while common thresher liver $\delta^{15} \mathrm{~N}$ was between the other liver values (Table 1). Thresher shark muscle $\delta^{15} \mathrm{~N}$ was higher (1.63 to $2.02 \%$ ) than that of muscle in blue sharks and shortfin makos. Common thresher cartilage $\delta^{15} \mathrm{~N}$ was moderately higher than that of the other 2 species and common thresher tissues were, on average, consistently higher in $\delta^{15} \mathrm{~N}$ than blue shark tissues. Cartilage $\delta^{15} \mathrm{~N}$ values were lowest among tissues in all 3 species.

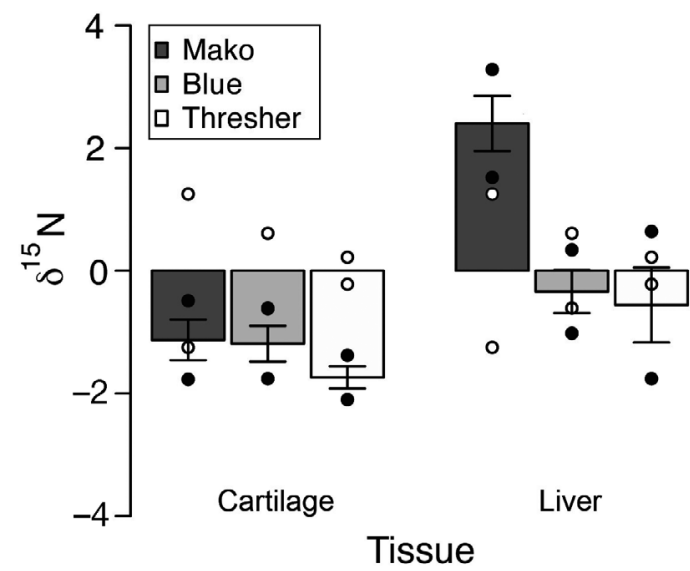

Fig. 2. Isurus oxyrinchus, Prionace glauca and Alopias vulpinus. Mean $\delta^{15} \mathrm{~N}$ differences between elasmobranch cartilage and liver tissues relative to muscle tissue. Baseline values (0) set to equal muscle $\delta^{15} \mathrm{~N}$ means. Standard deviation (error bars) and $95 \%$ confidence intervals (•) were calculated using non-parametric bootstrap estimates; (O) are muscle bootstrap $95 \%$ confidence intervals. Shortfin mako (mako), blue shark (blue) and common thresher (thresher) tissues were sampled from near Cape Cod, MA, July 2002 
Table 1. Isurus oxyrinchus, Prionace glauca and Alopias vulpinus. Mean $( \pm \mathrm{SD})$ multiple-tissue values of $\delta^{15} \mathrm{~N}$ and $\delta^{13} \mathrm{C}$ from non-parametric bootstrap estimates for sharks sampled from the George's Bank and Southern New England ecosystems in July, 2002. FL = fork length (cm)

\begin{tabular}{|lccc|}
\hline Tissue & $\begin{array}{c}\text { I. oxyrinchus } \\
(\mathrm{N}=5)\end{array}$ & $\begin{array}{c}\text { P. glauca } \\
(\mathrm{N}=14)\end{array}$ & $\begin{array}{c}\text { A. vulpinus } \\
(\mathrm{N}=5)\end{array}$ \\
\hline $\begin{array}{l}\text { Fork length (range) } \\
\text { Nitrogen }\end{array}$ & $203(178-232)$ & $259(220-281)$ & $208(185-339)$ \\
$\quad$ Liver & $15.36 \pm 0.45$ & $12.51 \pm 0.35$ & $13.93 \pm 0.61$ \\
$\quad$ Muscle & $12.93 \pm 0.64$ & $12.48 \pm 0.31$ & $14.50 \pm 0.11$ \\
$\quad$ Cartilage & $11.79 \pm 0.33$ & $11.67 \pm 0.29$ & $12.76 \pm 0.18$ \\
$\begin{array}{l}\text { Carbon } \\
\text { Liver }\end{array}$ & & & \\
$\quad$ Muscle & $-20.00 \pm 0.72$ & $-19.25 \pm 0.38$ & $-19.74 \pm 0.42$ \\
Cartilage & $-16.2 \pm 0.17$ & $-17.37 \pm 0.19$ & $-17.06 \pm 0.08$ \\
& $-13.71 \pm 0.15$ & $-14.93 \pm 0.35$ & $-14.40 \pm 0.17$ \\
\hline
\end{tabular}

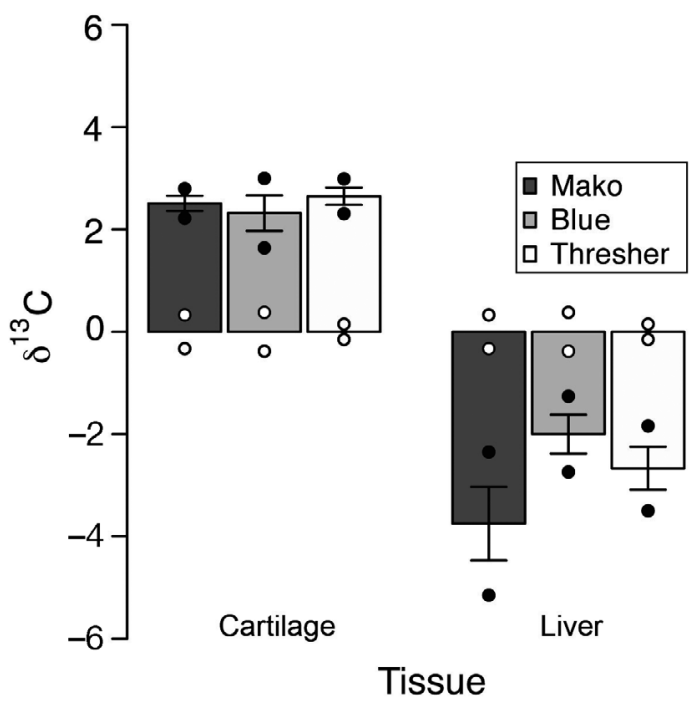

Fig. 3. Isurus oxyrinchus, Prionace glauca and Alopias vulpinus. Mean $\delta^{13} \mathrm{C}$ differences between elasmobranch cartilage and liver tissues relative to muscle tissue. Baseline values (0) set to equal muscle $\delta^{13} \mathrm{C}$ means. Standard deviation (error bars) and $95 \%$ confidence intervals $(\bullet)$ were calculated using non-parametric bootstrap estimates; (o) are muscle bootstrap $95 \%$ confidence intervals. Shortfin mako (mako), blue shark (blue) and common thresher (thresher) tissues were sampled from near Cape Cod, MA, July 2002

Each tissue had a distinct $\delta^{13} \mathrm{C}$ range that was independent of species (Table 1, Fig. 3) The closely matching $95 \%$ confidence intervals revealed that there were no apparent differences in the $\delta^{13} \mathrm{C}$ signature of each tissue among species. This pattern was exemplified by the common thresher $\delta^{13} \mathrm{C}$ values which were -19.74 for liver, -17.06 for muscle, and -14.4 for cartilage.

Bootstrap estimates of stable isotope variability within shark tissues was generally low (SD range: 0.08 to 0.72 ) and consistent with previous estimates from other studies on fish (Pinnegar \& Polunin 1999, Estrada et al. 2003).

\section{DISCUSSION}

Tieszen et al. (1983) were the first investigators to discuss the potential of exploiting metabolic differences among tissues to explain differences in stable isotope values, suggesting that $\delta^{13} \mathrm{C}$ differences among tissues of the gerbil Meriones unguienlatus were related to metabolic rate; the same was subsequently observed in laboratory experiments on birds by Hobson \& Clark (1992). MacNeil et al. (2005) found that inter-tissue differences in stable isotope levels in captive stingrays were related to the metabolic turnover rates of each tissue, demonstrating that liver $\delta^{15} \mathrm{~N}$ turned over twice as fast as in muscle and that cartilage turnover was slowest among tissues. Thus, stable isotopes of each metabolically distinct tissue represents a different period of feeding that decreases with increasing metabolic turnover. These results suggest that differences in stable isotope values among shark tissues from southern New England waters reflect a recent diet shift in shortfin makos and a consistent diet for blue sharks and common threshers. Differences in stable isotope values among tissues have not, to our knowledge, been reported in sharks under natural conditions. We were not surprised that cartilage $\delta^{15} \mathrm{~N}$ was lowest among tissues. Given that growth bands accrue slowly each year (Cailliet et al. 1986), changes in cartilage $\delta^{15} \mathrm{~N}$ would be expected to occur at a similar rate. These growth bands decrease in size as sharks grow and therefore the lower cartilage values observed in all 3 species were biased toward the accumulated $\delta^{15} \mathrm{~N}$ from younger ages (when they are feeding at a lower trophic level) than the muscle and liver samples.

The equivalence between muscle and liver $\delta^{15} \mathrm{~N}$ - in blue sharks and common threshers - indicates similarity between dietary $\delta^{15} \mathrm{~N}$ over the different feeding periods represented by each tissue (Fig. 2). This result implies that the fishes had been near steady-state with their diet during the previous year where - using the time to $95 \%$ turnover estimates for muscle (488 d) and liver (239 d) of MacNeil et al. (2005) - there was agreement between tissues. The potential for inter-tissue comparison of $\delta^{15} \mathrm{~N}$ to indicate steady-state feeding had not been suggested prior to the present study. Most modelling of stable isotope dynamics in laboratory animals has assumed that the individuals are at equilibrium with their diet (e.g. Hobson 1995), but this may not be the case for wild marine fishes with a widerange of seasonal diet choices. If we assume that a dynamic balance between tissue metabolism and diet 
composition determines the $\delta^{15} \mathrm{~N}$ and $\delta^{13} \mathrm{C}$ values of each tissue type (Figs. $2 \& 3$ ), agreement between tissues with different metabolic rates implies steady-state conditions in the diet. Stomach content analysis would be necessary to confirm this in each species, but the assumption allows several ecological inferences to be drawn from our $\delta^{15} \mathrm{~N}$ results.

The elevated $\delta^{15} \mathrm{~N}$ in shortfin mako liver versus muscle and cartilage directly correlates with well known seasonal shifts in shortfin mako diet and bluefish Pomatomus saltatrix migration. Mako sharks from south of Martha's Vineyard are part of a northwest Atlantic population that has distinct inshore (on shelf) and offshore (off shelf) feeding groups (Stillwell \& Kohler 1982, Heist et al. 1996). The inshore population feeds almost exclusively on bluefish in the summer, despite the availability of inshore cephalopods (Stillwell \& Kohler 1982). Bluefish migrate inshore each spring for summer spawning. They remain resident there until the late fall (Oliver et al. 1989, Salerno et al. 2001) and, because they are the highest trophic species consumed by shortfin makos below $150 \mathrm{~kg}$ (Stillwell \& Kohler 1982), will increase mako $\delta^{15} \mathrm{~N}$ values above those resulting from ingestion of cephalopod prey.

The makos caught for our study were from the inshore shelf waters in July, and the elevated $\delta^{15} \mathrm{~N}$ in their high-metabolism livers correlated well with a springtime diet switch from cephalopods to summer spawning bluefish. Bluefish and squid muscle $\delta^{15} \mathrm{~N}$ sampled from the south of Martha's Vineyard in 2001 averaged 16.3\% (J. Estrada unpubl.) and 12.7\% (Estrada et al. 2003), respectively. Given the 90+ d from the May diet switch to bluefish to our time of sampling, and given that time to $50 \%$ liver turnover in laboratory-reared stingrays has been estimated at about $55 \mathrm{~d}$ (MacNeil et al. 2005), the $2.43 \%$ increase in liver over muscle $\delta^{15} \mathrm{~N}$ appears to have recorded the seasonal trophic shift in shortfin mako diet. These seasonal shifts in distribution and diet were also noted by Estrada et al. (2003) as the potential source of variability in muscle $\delta^{15} \mathrm{~N}$. Mako sharks have a metabolism that is among the highest known for shark species (Carlson et al. 2004) and their liver $\delta^{15} \mathrm{~N}$ values should more rapidly reflect any change in $\operatorname{diet} \delta^{15} \mathrm{~N}$. The lower $\delta^{15} \mathrm{~N}$ values of muscle with its slower metabolism correlated with the expected lower $\delta^{15} \mathrm{~N}$ of the previous winter's cephalopod prey.

The consistency in $\delta^{15} \mathrm{~N}$ among blue shark tissues agrees with stomach content conclusions that this species is a generalist predator (Cortés 1999, Henderson et al. 2001, McClelland et al. 2003), and suggests that the fish were near $\delta^{15} \mathrm{~N}$ steady-state with a consistently heterogeneous diet. Based on published stomach content studies, Cortés (1999) summarized the yearly average blue shark diet world-wide as nearly equal parts cephalopods (49.4\%) and fishes (38.5\%), although this is not always the case.

Henderson et al. (2001) reported that blue shark stomach contents off Ireland were dominated by cephalopods, which are common prey species in the area. Vas (1990) suggested from stomach content results that blue sharks prey on the most locally abundant pelagic species, and Henderson et al. (2001) supported this conclusion. NOAA fall sampling surveys for the area south of Martha's Vineyard sampled in this study showed that cephlaopod and fish species known to be blue shark prey were readily available (NMFS 2002). It is likely that the blue sharks sampled fed in the generalist mode suggested by Cortés (1999) and our tissue-specific $\delta^{15} \mathrm{~N}$ results.

The consistency observed between common thresher liver and muscle $\delta^{15} \mathrm{~N}$ values (Fig. 2) also suggests a consistent diet similar to the blue shark, and one near steady-state. Little has been published regarding common thresher diet. Cortés (1999) found (in percent occurrence) a predominantly cephalopod diet (71.8\%) with some fishes $(26.7 \%)$; however, the results relied on a single sampling study in Mexico. Preti et al. (2001) examined common threshers in Californian waters to find (by index of relative importance) a fish-dominated diet regime. Bowman et al. (2000) found that $97 \%$ of common thresher stomachs from the northwest Atlantic contained fishes. With such disparate results, common thresher diet in the sampling area could range from entirely fishes to entirely cephlaopods. Estrada et al. (2003) noted these difficulties, but posed that their results most closely matched the data from Cortés (1999). Relative to the $\delta^{15} \mathrm{~N}$ results for shortfin makos sampled in the area, the thresher $\delta^{15} \mathrm{~N}$ results imply a mixed diet of mid to high trophic level fish and cephalopods. Mean thresher muscle and cartilage $\delta^{15} \mathrm{~N}$ values were higher than those of both blue sharks and shortfin makos, implying (on a yearly average) a somewhat higher trophic level diet than the other species. Stomach content analysis of common thresher diet could, of course, validate the generalist diet suggested by our results, but without such data we can only say that there is no evidence of a large mean annual trophic shift in this species.

Although there was some overlap between adjacent groups, a distinct pattern emerged from $\delta^{13} \mathrm{C}$ results among tissues (Fig. 3). Liver $\delta^{13} \mathrm{C}$ was lower than that in muscle and cartilage, in a pattern similar to that observed in rainbow trout by Pinnegar \& Polunin (1999). Results from the present study and those of Pinnegar \& Polunin (1999) show that liver tissue is depleted in $\delta^{13} \mathrm{C}$ relative to muscle tissue, and that $\delta^{13} \mathrm{C}$ values decrease with increasing metabolic rates of the tissues. Pinnegar \& Polunin (1999) explained much of the initial variance among tissues in terms of the lipid 
content, where more lipids led to lower $\delta^{13} \mathrm{C}$ values. However, after lipid removal, the relationship between $\delta^{13} \mathrm{C}$ and metabolic rate remained, a result for which Pinnegar \& Polunin (1999) provided no explanation. We removed lipids from our samples.

Similar to $\delta^{15} \mathrm{~N}, \delta^{13} \mathrm{C}$ is known to vary with amino acids (Hare et al. 1991), and we suspect that the pattern in $\delta^{13} \mathrm{C}$ values among tissues reflects routing of $\delta^{13} \mathrm{C}$-specific amino acids to each tissue. No studies of $\delta^{13} \mathrm{C}$ variation among amino acids have been conducted on fishes.

It is possible that differences in $\delta^{13} \mathrm{C}$ values among tissues reflect a diet switch from cephalopod prey (muscle values) to bluefish prey (liver values). However, food web sampling has shown the $\delta^{13} \mathrm{C}$ range for potential prey in these waters to be between -21.9 and -16.9 (J. Estrada unpubl.). That some tissues fell well outside this range suggests a metabolic, rather than a dietary, mechanism for our observed $\delta^{13} \mathrm{C}$ values among sharks (Fig. 3) and infers that comparison among tissue $\delta^{13} \mathrm{C}$ values is unsuitable for tracking temporal diet shifts in sharks.

Our $\delta^{13} \mathrm{C}$ values for shortfin mako muscle (mean \pm SD: $-16.2 \pm 0.17 \%$ ) were somewhat higher than local $\delta^{13} \mathrm{C}$ values for cephalopods $(-17.8 \pm 0.39 \%$; Estrada et al. 2003) and bluefish $(-17.94 \pm 0.36 \%$; J. Estrada unpubl.), and were greater than the commonly cited $\pm 1 \%$ conservation of $\delta^{13} \mathrm{C}$ between consumer and diet muscle tissues (Polunin \& Pinnegar 2002). $\delta^{13} \mathrm{C}$ has been used previously to differentiate between inshore $\left(\delta^{13} \mathrm{C}\right.$ enirched) and offshore $\left(\delta^{13} \mathrm{C}\right.$ depleted $)$ carbon sources (France 1995), and the enriched shortfin mako values may reflect a diet contribution from an unknown inshore diet source. The overlap of blue shark and common thresher muscle $\delta^{13} \mathrm{C}$ results indicates that these species were exploiting similar sources of dietary carbon, and these results correlate well with the results of Estrada et al. (2003).

Our data were likely correlated to some degree in that 3 tissues were sampled from each fish captured. There was no evidence however, of an individual fish affect on the results due to the agreement between the raw data and the independent bootstrap estimates among tissues. To estimate trophic position from these values would require detailed $\delta^{15} \mathrm{~N}$ and dietary data for the entire food web. As there have been no studies to validate $\delta^{15} \mathrm{~N}$ fractionation in sharks, we could not determine the percentage of actual fractionation that our isotope values represented (e.g. the apparent $2.4 \%$ $\delta^{15} \mathrm{~N}$ differences between mako liver and muscle tissue). A $3.4 \%$ fractionation in $\delta^{15} \mathrm{~N}$ is often cited as representative of a trophic level increase between a consumer and its diet. The seasonal cephalopod-bluefish diet switch for shortfin mako (Stillwell \& Kohler 1982) and the difference between shortfin mako liver and muscle results would suggest a half trophic level diet shift for shortfin mako in the previous few months. Estimating shortfin mako fractionation among tissues would help evaluate this hypothesis. This could be done through controlled feeding experiments of juve-

Table 2. Means $( \pm \mathrm{SD})$ and ranges of muscle $\delta^{15} \mathrm{~N}$ and $\delta^{13} \mathrm{C}$ values for animal species from George's Bank and Southern New England. Results for Estrada et al. (2003) are from July-August 2001 and for this study are from July 2002

\begin{tabular}{|c|c|c|c|c|c|}
\hline \multirow[t]{2}{*}{ Species } & \multirow[t]{2}{*}{$\mathrm{N}$} & \multicolumn{2}{|c|}{$\delta^{15} \mathrm{~N}$} & \multicolumn{2}{|c|}{$\delta^{13} \mathrm{C}$} \\
\hline & & Mean $\pm \mathrm{SD}$ & Range & Mean \pm SD & Range \\
\hline \multicolumn{6}{|l|}{ This study $^{\mathrm{a}}$} \\
\hline Prionace glauca & 14 & $12.5 \pm 0.31$ & 11.6 to 16.2 & $-17.4 \pm 0.19$ & -18.7 to -16.3 \\
\hline Isurus oxyrinchus & 5 & $12.9 \pm 0.64$ & 11.6 to 15.0 & $-16.2 \pm 0.17$ & -16.5 to -15.6 \\
\hline Alopias vulpinus & 5 & $14.5 \pm 0.11$ & 14.1 to 14.8 & $-17.1 \pm 0.08$ & -17.4 to -16.9 \\
\hline \multicolumn{6}{|l|}{ Estrada et al. (2003) } \\
\hline Prionace glauca & 5 & $13.1 \pm 0.25$ & 12.5 to 13.7 & $-16.9 \pm 0.10$ & -17.1 to -16.5 \\
\hline Isurus oxyrinchus & 5 & $13.6 \pm 0.48$ & 12.2 to 15.2 & $-16.6 \pm 0.23$ & -17.1 to -15.9 \\
\hline Alopias vulpinus & 4 & $15.2 \pm 0.14$ & 14.8 to 15.5 & $-17.5 \pm 0.08$ & -17.7 to -17.3 \\
\hline Cetorhinus maximus & 1 & 10.4 & & -22.5 & \\
\hline Copepod spp. ${ }^{\mathrm{b}}$ & & 7.1 & 7.0 to 7.3 & -21.8 & -22.2 to -21.4 \\
\hline Ammodytes americanus & 6 & $10.2 \pm 0.09$ & 9.9 to 10.5 & $-21.0 \pm 0.24$ & -21.9 to -20.2 \\
\hline Merluccius bilinearis & 5 & $11.1 \pm 0.14$ & 10.8 to 11.5 & $-18.7 \pm 0.14$ & -19.1 to -18.4 \\
\hline Clupea harengus & 2 & 11.3 & $10.7,11.9$ & $-21.1,-21.1$ & \\
\hline Squid spp. & 9 & $12.7 \pm 0.20$ & 11.9 to 13.7 & $-17.8 \pm 0.39$ & -19.8 to -17.0 \\
\hline \multicolumn{6}{|l|}{ J. Estrada (unpubl. data) } \\
\hline Pomatomus saltatrix & NA & $16.3 \pm 0.26$ & & $-17.9 \pm 0.36$ & \\
\hline
\end{tabular}


niles in the laboratory, or through detailed dietary and stable isotope sampling in the field.

A comparison of our muscle isotope data with that of Estrada et al. (2003) is presented in Table 2. Despite the year between studies, the results of Estrada et al. (2003) parallel our own in several key aspects. The relative $\delta^{15} \mathrm{~N}$ values among shark species fall into similar rankings, i.e. common thresher, shortfin mako, and blue shark in decreasing $\delta^{15} \mathrm{~N}$ order. Such betweenyear agreement implies that relative trophic positions among shark species are consistent between adjacent years and that these relative values may have some degree of stability over time. An implication of the results is that $\delta^{15} \mathrm{~N}$ data may be useful for monitoring relative trophic position of large-pelagic fishes over time.

\section{CONCLUSIONS}

This study shows that stable-isotope analysis of multiple tissues can provide greater trophic resolution than the use of muscle tissue alone and can be used to monitor trophic dynamics in sharks, implying that metabolic differences among tissues can be exploited to more precisely characterize the trophic dynamics of fishes. Specifically, this study showed that relative isotope compositions of shark tissues can elucidate the known seasonal feeding dynamics of inshore shortfin makos and their bluefish prey and support the suspected trophic roles of blue sharks and common threshers as year-round generalist predators in the northwest Atlantic. Poor agreement between stable isotope analysis and stomach content analysis has suggested previously that careful temporal sampling using both techniques is required to observe the true variability of fish diets (Harvey et al. 2002). While good stomach content data will continue to be necessary, multiple-tissue sampling can exploit differences in tissue metabolism to discern trophic dynamics with a minimum of sampling effort (Kurle \& Worthy 2002). This is particularly important for sampling of large pelagic fishes that are logistically intensive to sample and about which little dietary information is known. Relative isotope composition data also has the potential to reduce the amount of sampling required to monitor trophic-dynamic changes in fish, once a baseline diet pattern has been established through traditional stomach sampling. Used together, these data sources can help to improve understanding of the trophic implications of predator removals from marine ecosystems.

Despite the reported agreement between Cortés (1999) and Estrada et al. (2003), we believe a much wider sampling regime is required to evaluate the appropriateness of stable isotope analysis for estimation of trophic position in sharks. These fishes are physiologically unique, and little is known about how stable isotopes pass through their digestive system and are incorporated into tissues. Sampling from a wide range of species for stable isotopes will ultimately determine the usefulness of the stable isotope method in pelagic environments. We strongly encourage the use of multiple-tissue sampling in stable isotope analyses (1) to capture trophic shifts, (2) to estimate steadystate conditions, and (3) to increase the quantity of trophic information available from each sampled fish.

Acknowledgements. We thank M. Rigglesford for sample preparation, T. Maddox for stable isotope analysis, and the many recreational fishermen in Oak Bluffs for access to their catch. Thanks to J. Estrada for additional isotope samples. Thanks to G. Benz, G. Grossman and 3 anonymous reviewers for helpful comments on the manuscript. This research was funded through the Warnell School of Forest Resources at the University of Georgia.

\section{LITERATURE CITED}

Anderson D, Burnham K, Thompson W (2000) Null hypothesis testing: problems, prevalence, and an alternative. J Wildl Manag 64:912-923

Baum J, Myers R (2004) Shifting baselines and the decline of pelagic sharks in the Gulf of Mexico. Ecol Lett 7:135-145

Baum J, Myers R, Kehler D, Worm B, Harley S, Doherty P (2003) Collapse and conservation of shark populations in the Northwest Atlantic. Science 299:389-392

Bowman R, Stillwell C, Michaels W, Grosslein M (2000) Food of Northwest Atlantic fishes and two common species of squid. Tech. Rep. NMFS-NE-155. National Marine Fisheries Service, Mashpee, MA

Cailliet GM, Radtke RL, Weldon BA (1986) Elasmobranch age determination and verification: a review. In: Uyeno T, Arai R, Taniuchi T, Matsuura K (eds) Indo-Pacific fish biology. Proc 2nd Int Conf Indo-Pacific Fishes. Ichthyological Society of Japan, Tokyo, p 345-360

Carlson J, Goldman K, Lowe C (2004) Metabolism, energetic demand, and endothermy. In: Carrier JC, Musick JA, Heithaus MR (eds) Biology of sharks and their relatives. CRC Mar Biol Series. CRC Press, Boca Raton, FL, p 203-224

Charles A (2001) Sustainable fishery systems. Fish and aquatic resources series 5. Blackwell Science, London

Cortés E (1999) Standardized diet compositions and trophic levels of sharks. ICES J Mar Sci 56:707-717

Cox S, Essington T, Kitchell J, Martell S, Walters C, Boggs C, Kaplan I (2002) Reconstructing ecosystem dynamics in the central Pacific Ocean, 1952-1998. II. A preliminary assessment of the trophic impacts of fishing and effects on tuna dynamics. Can J Fish Aquat Sci 59:1736-1747

Essington $T$, Schindler D, Olson R, Kitchell J, Boggs C, Hilborn R (2002) Alternative fisheries and the predation rate of yellowfin tuna in the eastern Pacific Ocean. Ecol Appl 12:724-734

Estrada JA, Rice AN, Lutkavage ME, Skomal GB (2003) Predicting trophic position in sharks of the north-west Atlantic Ocean using stable isotope analysis. J Mar Biol Assoc UK 83:1347-1350 
Fisk AT, Tittlemier SA, Pranschke JL, Norstrom RJ (2002) Using anthropogenic contaminants and stable isotopes to assess the feeding ecology of greenland sharks. Ecology 83:2162-2172

France RL (1995) Carbon-13 enrichment in benthic compared to planktonic algae: foodweb implications. Mar Ecol Prog Ser 124:307-312

Hare P, Fogel M, Stafford T, Mitchell A Jr, Hoering T (1991) The isotopic composition of carbon and nitrogen in individual amino acids isolated from modern and fossil proteins. J Arch Sci 18:277-292

Harvey CJ, Hanson PC, Essington TE, Brown PB, Kitchell JF (2002) Using bioenergetics models to predict stable isotope ratios in fishes. Can J Fish Aquat Sci 59:115-124

Heist EJ, Musick JA, Graves JE (1996) Genetic population structure of the shortfin mako (isurus oxyrinchus) inferred from restriction fragment length polymorphism analysis of mitochondrial DNA. Can J Fish Aquat Sci 53:583-588

Henderson AC, Flannery K, Dunne JA (2001) Observations on the biology and ecology of the blue shark in the north-east atlantic. J Fish Biol 58:1347-1358

Hobson KA (1995) Reconstructing avian diets using stable carbon and nitrogen isotope analysis of egg components: patterns of isotopic fractionation and turnover. Condor 97: $752-762$

Hobson KA, Clark RG (1992) Assessing avian diets using stable isotopes I: turnover of ${ }^{13} \mathrm{C}$ in tissues. Condor 94: 181-188

Hobson KA, Welch HE (1992) Determination of trophic relationships within a high Arctic marine food web using $\delta^{15} \mathrm{~N}$ and $\delta^{13} \mathrm{C}$ analysis. Mar Ecol Prog Ser 84:9-18

Hobson K, Gilchrist G, Falk K (2002) Isotopic investigations of seabirds of the north water polynya: contrasting trophic relationships between the eastern and western sectors. Condor 104:1-11

Jackson J, Kirby M, Berger W, Bjorndal K and 15 others (2001) Historical overfishing and the recent collapse of coastal ecosystems. Science 293:629-638

Johnson D (1999) The insignificance of statistical significance testing. J Wildl Manag 63:763-772

Kitchell JF, Essington TE, Boggs C, Schindler DE, Walters C (2002) The role of sharks and longline fisheries in a pelagic ecosystem of the central pacific. Ecosystems 5: 202-216

Kurle CM, Worthy GAJ (2002) Stable nitrogen and carbon isotope ratios in multiple tissues of the northern fur seal Callorhinus ursinus: implications for dietary and migratory reconstructions. Mar Ecol Prog Ser 236:289-300

MacNeil M, Drouillard K, Fisk A (2005) Variable uptake and elimination of stable nitrogen isotopes. Can J Fish Aquat Sci (in press)

McClelland J, Holl C, Montoya J (2003) Relating low $\delta^{15} \mathrm{~N}$ values of zooplankton to $\mathrm{N}_{2}$-fixation in the tropical North Atlantic: insigts provided by stable isotope ratios of amino acids. Deep-Sea Res I 50:849-861

Minagawa M, Wada E (1984) Stepwise enrichment of ${ }^{15} \mathrm{~N}$

Editorial responsibility: Otto Kinne (Editor-in-Chief), Oldendorf/Luhe, Germany along food chains: further evidence and the relation between $\delta^{15} \mathrm{~N}$ and animal age. Geochim Cosmochim Acta 48:1135-1140

Myers RA, Worm B (2003) Rapid worldwide depletion of predatory fish communities. Nature 423:280-283

NMFS (National Marine Fisheries Service) (2002) Fisherman's report: bottom trawl survey. National Marine Fisheries Service Tech Rep, Northeast Fisheries Science Center, Woods Hole, MA

Oliver J, Van Den Avyle M, Bozeman E Jr. (1989) Species profiles: life histories and environmental requirements of coastal fishes and invertebrates (South Atlantic) bluefish). Reports 82(11). U.S. Fish and Wildlife Service, Slidell, LA

Pinnegar JK, Polunin NVC (1999) Differential fractionation of $\delta^{15} \mathrm{C}$ and $\delta^{15} \mathrm{~N}$ among fish tissues: implications for the study of trophic interactions. Funct Ecol 13:225-231

Pinnegar JK, Campbell N, Polunin NVC (2001) Unusual stable isotope fractionation patterns observed for fish hostparasite trophic relationships. J Fish Biol 59:494-503

Polunin N, Pinnegar J (2002) Trophic ecology and the structure of marine food webs. In: Hart P, Reynolds J (eds) Handbook of fish and fisheries, Vol 1. Blackwell Science, Oxford, p 301-320

Preti A, Smith S, Ramon D (2001) Feeding habits of the common thresher shark (Alopias vulpinus) sampled from the California-based drift gill net fishery, 1998-1999. Calif Coop Ocean Fish Investig Rep 42:145-152

Renones O, Polunin NVC, Goni R (2002) Size related dietary shifts of epinephelus marginatus in a western mediterranean littoral ecosystem: an isotope and stomach content analysis. J Fish Biol 61:122-137

Salerno DJ, Burnett J, Ibara RM (2001) Age, growth, maturity, and spatial distribution of bluefish, pomatomus saltatrix (linneaus), off the northeast coast of the united states, 1985-96. J Northwest Atl Fish Sci 29:31-39

Schoeller DA (1999) Isotope fractionation: why aren't we what we eat? J Arch Sci 26:667-673

Stevens JD, Bonfil R, Dulvy NK, Walker PA (2000) The effects of fishing on sharks, rays, and chimeras (chondricthyans), and the implications for marine ecosystems. ICES J Mar Sci 57:476-494

Stillwell C, Kohler N (1982) Food, feeding habits, and estimates of daily ration of the shortfin mako (Isurus oxyrinchus) in the Northwest Atlantic. Can J Fish Aquat Sci 39:407-414

Tieszen LL, Boutton TW, Tesdahl KG, Slade NA (1983) Fractionation and turnover of stable carbon isotopes in animal tissues: implications for $\delta^{15} \mathrm{~N}$ analysis of diet. Oecologia 57: 32-37

Vander Zanden MJ, Cabana G, Rasmussen JB (1997) Comparing trophic position of freshwater fish calculated using stable nitrogen isotope ratios $\left(\delta^{15} \mathrm{~N}\right)$ and literature dietary data. Can J Fish Aquat Sci 54:1142-1158

Vas P (1990) The abundance of the blue shark, prionace glauca, in the western english channel. Environ Biol Fish 29:209-225

Submitted: November 5, 2004; Accepted: May 12, 2005

Proofs received from author(s): September 20, 2005 